\title{
繊維形態の紙質に与える影響及び新型繊維長測定器 FiberLab*
}

\author{
バルメットオートメーションカヤーニ株式会社マルコ カウピネン \\ バルメットオートメーション株式会社 ○坂 田 秀 実
}

\section{Fiber Dimensions \\ -Their Effect on Paper Properties \& Required Measuring Accuracy}

Marko Kauppinen

Valmet Automation Kajaani Ltd.

Hidemi Sakata

Valmet Automation K.K.

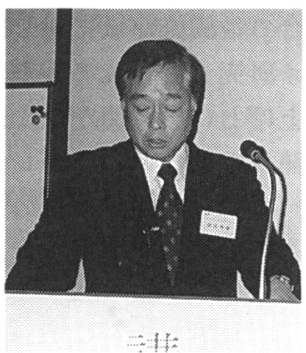

坂田秀実

The dimensions of raw wood fibers used in papermaking vary considerably. In the process, fiber dimensions can be changed by various treatments and their size distribution can be altered. Fiber dimensions play a crucial roles in the development of many paper properties, particulary its strength, and contribute to the optical and surface properties of paper.

Fiber properties can be classified into morphological, structural and chemical propertis. For softwood kraft, the most important by far is cell wall thickness. Fiber length and coarseness can be measured reliably with currently available fiber analyzers.

No automatic instrument had exited as yet for cell wall thickness; and the resolution of currently available analyzers was still very coarse even for fiber width measurement; however, with the aid of latest optical technology, Valmet Automation Kajaani Ltd. has developed FiberLab with which now can offer 1 um resolution.

The followings are the characteristics of FiberLab.

1. paper properties can be predicted with superior accuracy with the new measurements.

2. Fiber length, width and call wall thichness from single fibers in the sample.

3. Fiber length measurements according to TAPPI standard T271. - Able to determine the ratio of three different wood species in a blend.

4. Fiber width and cell wall thickness measurement with 1 um resolution.

5. Measure thousands of fibers in only 8 minutes.

Together with those characteristics of FiberLab, we'd like to mention the effect of dimensions, especially wall thickness, of fibers on paper properties such as tensile strength, tear strength and tear strenght etc. This report summarizes the effects of various fiber dimensions of paper properties and outlines the repuired measuring accuracy.

*第 3 回パルプ基礎講座「機械パルプと非木材パルプ」講演報文 


\section{1.はじめに}

従来の方法としては，フリーネス測定とバウアーマ クネットのふるい分け法に見られる繊維の残留物に対 する種々の性質を測定しようとするものであった。繊 維長測定は過去 15 年間にわたって世の中に広まって きたし, また自動繊維長分析器も有効なものとして受 け入れられてきた。

木材と紙シートの密度を使って木材繊維の粗度（単 位長さ当たりの重量）が，紙の性質に対してどのよう な効果を与えるか間接的に研究されてもきた。そして, ある繊維長測定器によれば繊維の粗度さえ求めること が出来る。絡み合った纎維が紙に対してどのような効 果を生むかという研究もなされているが，この作業は 顕微鏡的な数え上げという時間がかかって圥長である ということから簡単ではない。このレポートは，種々 の大きさ（次元）を持った繊維が紙の性質に与える効 果をまとめているもので, 必要とされる測定精度の図 表を提出する。

\section{2.ある大きさ（次元）を持った繊維と紙の性質}

\section{1 繊 維 長}

纎維長と引き裂き強さ及び引っ張り強さの間を関連 付ける研究は，いくつか行われ実証されてきた。この 相関は図 1 と図 2 に示される。より長い纎維長を持つ 紙は，より強い性質を持つ。一般的に受け入れられて いる強度理論によれば，破壊部分の間をわたる繊維の 伸びは紙の引っ張り強さにより求められ, 引き裂き強 さに対し最も重要な要素の一つであるということであ る。もし瀻維が短かければ，破裂線を横断する纎維に 比例して引っ張り強さは小さくなる。纎維長の範囲が 1 2.5 mmの間にある時の相関は線形であるが, 緎 維長と引つ張り強さとの間の関係は, 高い吒解度に於 いて，より顕著となる。引き裂き強さもまた，繊維長 の範囲が少なくとも $2.5 \mathrm{~mm}$ 以下に於いて線形関係に ある。しかしながら, 異なる研究から見いだされた結 果には違いが僅かにある。その理由の一つに, 繊維の 粗度は繊維長により変化し，さらに増幅あるいは抑制 されるかもしれないからである。(図 3参照)。一つの 例を出すと，長く大きな纎維は高い粗度を持つが，一 方で, 長い繊維長は強い引っ張り強さを与え, 高い粗 度は反対の効果を持つ。

加工しない木材の纎維での大きさ（次元）は，製紙 に於いてかなりよく使われる。このプロセスでは, 繊 維の大きさは種々の加工により変化させられ，長さ分 布は部分的に変化する。纎維の大きさは色々な紙質の
TENSILE INDEX, $\mathrm{Nm} / \mathrm{g}$

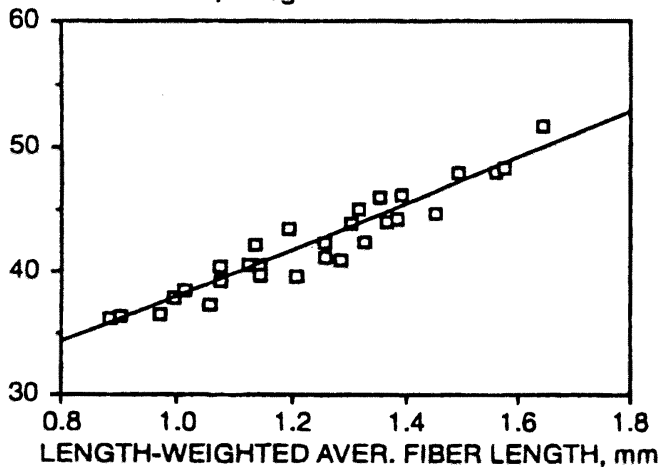

Fig.1 Effect of fiber length on tensile index ; kraft + TMP $/ 3 /$.

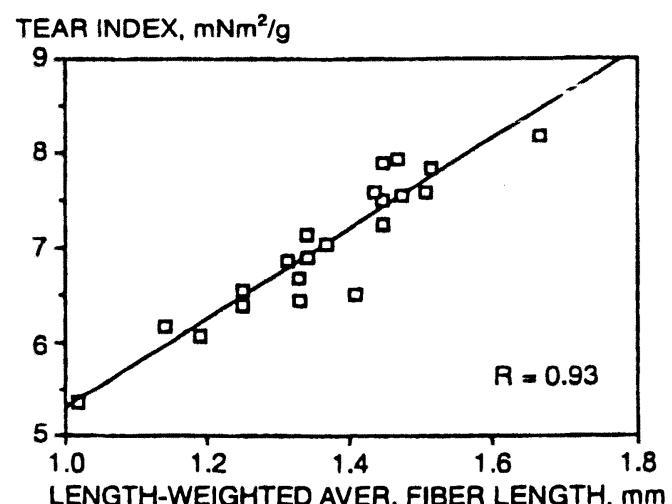

Fig.2 Effect of fiber length on tear index ; newsprint $\mathrm{TMP} / 3 /$.

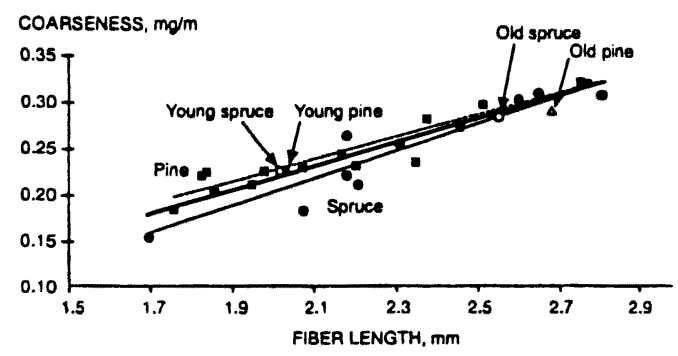

Fig.3 Relationship between fiber length and coarseness ; sofrwood kraft fibers/6/.

変化を見るのに決定的な役割を果たすが，特に紙の強 さに於いて顕著であり, 紙の光学的性質及び表面の性 質の主要な原因でもある。

繊維の性質については, 形態学的, 構造的, 化学的 に分類出来る。ソフトウッドについて言えば，何より も重要な大きさ（次元）はセルウォールシックネスで ある。繊維長と粗度は今では有効な分析器により確実 
に測定できる。セルウォールシックネスに对して自動 的に測定する機械は今日まだ存在していないし，緘維 の直径を測定することさえまだ極めて粗い分解能を持 つ分析器が存在するだけである。

\section{2 瀻維の粗度}

繊維の粗度は色々な要因に依存している。例えば, 木の材種，木の育成条件，幹中の位置などである。破 裂線を横断する纎維の大きさは, 中央部と茎部, 中心 部と樹皮部とで異なり, 繊維の粗度は標準的方法によ れば生産されたペーパーシートと加工しない木材との 絶乾密度が要因となって決まる。繊維粗度が紙質に及 ぼす効果は, いくらかの時間を経て木材とぺーパーシ 一トの密度を比較することにより, 間接的に研究され てきた。

絶乾木材の密度は, 幹中のセルウォールと空気の割 合に依存し,さらにファイバーウォールシックネスに 依存している。つまり，厚みのある繊維壁は高い密度 を与えるのである。これは木材密度のある纎維は高い 粗度を持ち, 木材密度の低い繊維よりも堅いというこ とを意味している (図 4 参照)。この結論は違う研究 によっても支持されている。

堅い繊維はあまりよく結合しないが，相対的に広い ネットワークを形成する。このように, 堅い木材瀻維 からなる紙は低い紙力と密度を持ち，その表面は粗く 空気の透過性は高くなる。図 5 と図 6 には, 絶乾木材 密度が引っ張り及び引き裂き強さに与える効果を示し ている。引っ張り強さは, 高い木材密度に対して低減 する。なぜなら, 纎維粗度が増加すると同時に結合す る纎維が減少していく。他方で, リファインされた繊

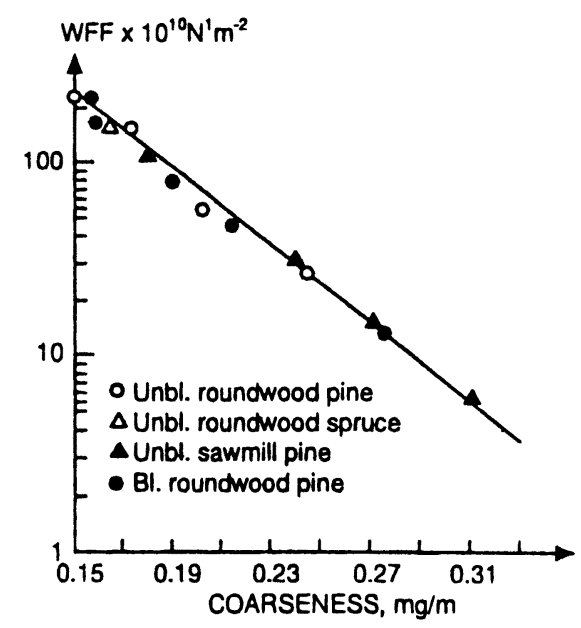

Fig.4 Effect of coarseness on wet fiber flexibility $/ 21 /$.

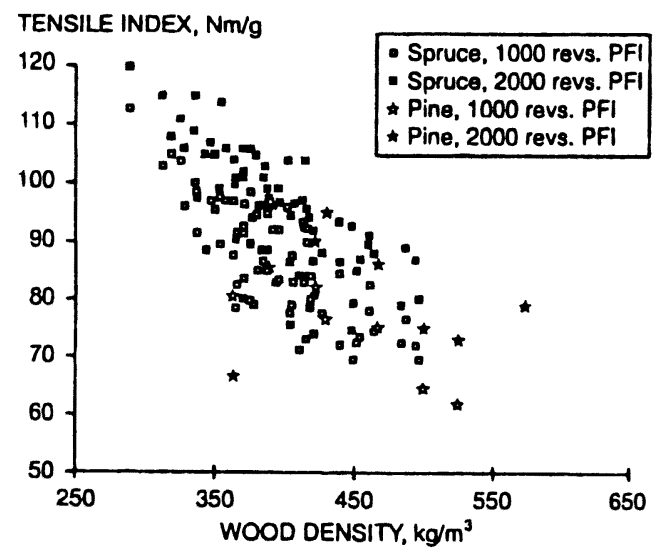

Fig.5 Effect of wood density on the tensile index of paper sheets; softwood kraft fibers $/ 7,11 /$.

TEAR INDEX, $\mathrm{mNm}^{2} / \mathrm{g}$

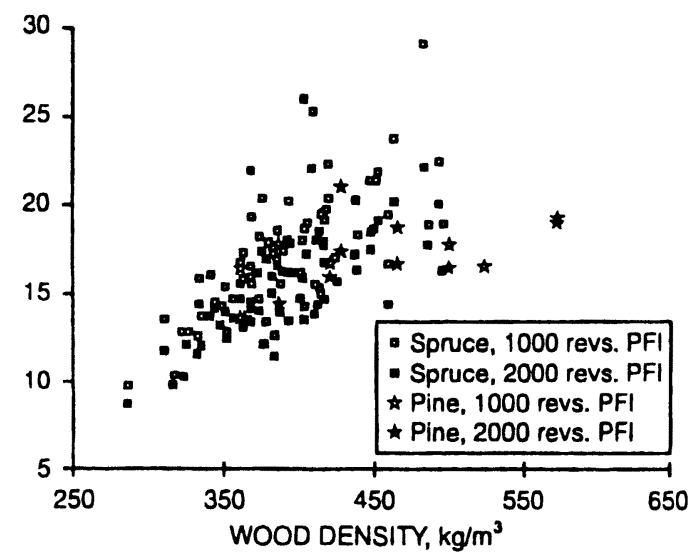

Fig. 6 Effect of wood density on the tear index of paper sheets; softwood kraft fibers/7, 11/.

維からなる紙の引き裂き強度は, 木材密度とともに増 加していく。十分な結合能力を持つ粗い瀻維は，低い 粗度を持つ繊維よりも，引き裂き力に対して持ちこた える力を保持している。

繊維の堅さと粗度の要因には, ペーパーシート密度 がある。この結果からは, 紙力と散乱光に対してシー 卜密度が影響するように思われる。シート密度と引っ 張り及び引き裂き強さの関係は, 図 7 と図 8 に示す。

図 9 には, シート密度が紙の光の散乱率に与える効 果を示している。散乱光は, 全シート表面の繊維数, 外部繊維の大きさ, ルーメンの崩壊, 繊維の結合度合 いにより決まる。光の散乱率は, 弱い結合と粗い瀻維 からなる低い密度の紙に対して高くなる。 


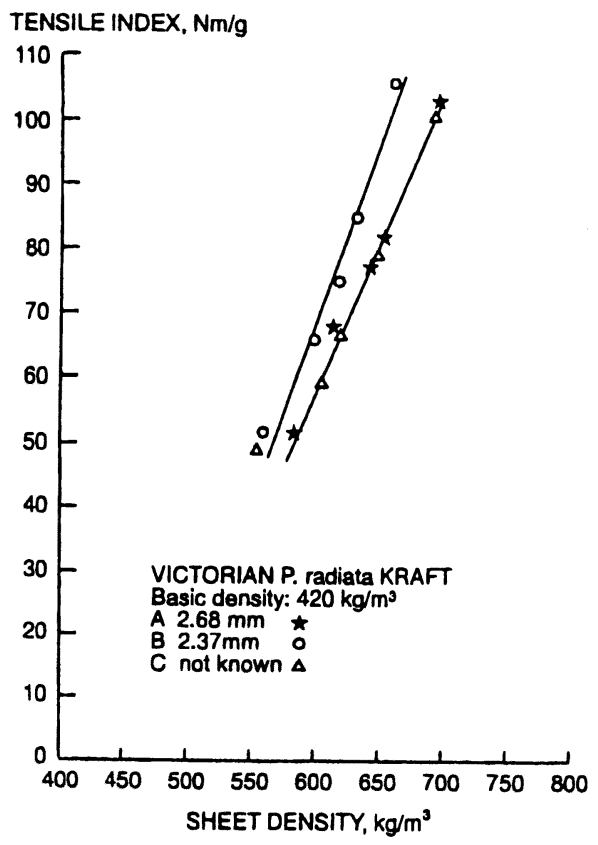

Fig.7 Effect of paper sheet density on the tensile index of paper; softwood kraft fibers/19/.

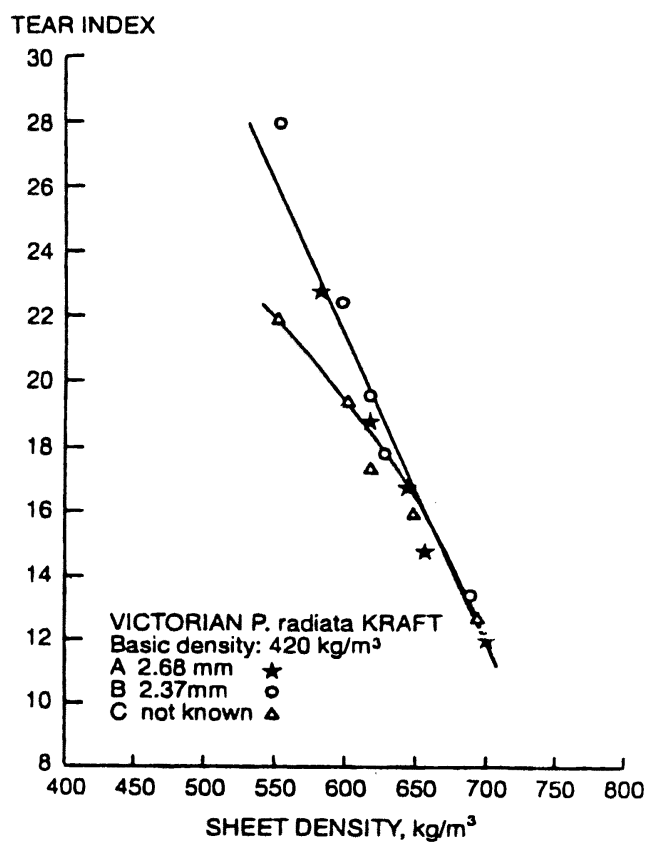

Fig. 8 Effect of paper sheet density on the tear index of paper; softwood kraft fibers/19/.

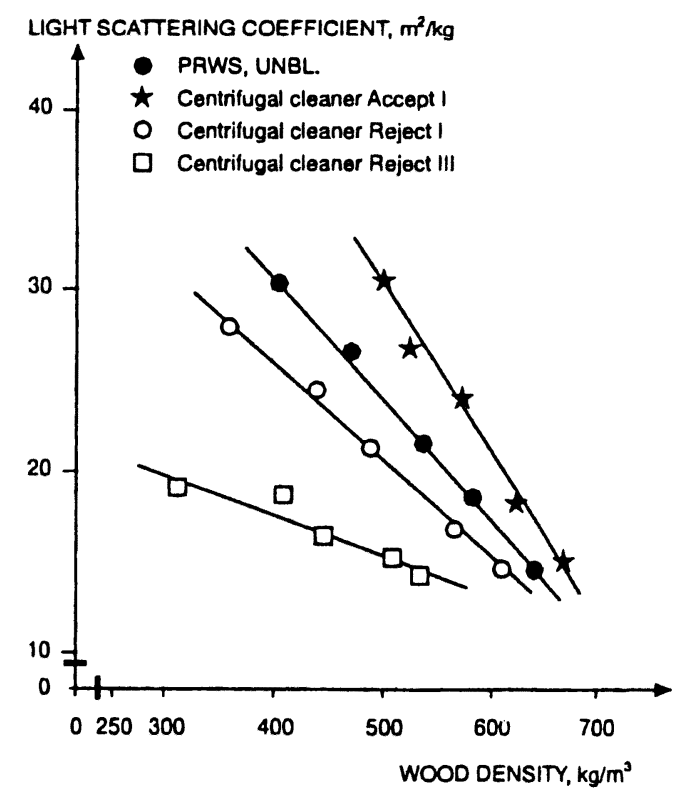

Abbreviations used in Fig. 9-24:

PRWS -pine roundwood chip pulp, southern Finland SRWS -spruce roundwood chip pulp, southern Finland PSMS - pine sawmill chip pulp, southern Finland PRWN -pine roundwood chip pulp, northern Finland

Fig.9 Effect of apparent sheet density on the light scattering coefficient; softwood kraft fibers/24/.

繊維粗度は, 蒸解, 漂白, 吒解（精選）のような工 程によって変わってくる。図 10 において，カッパ-価 で表されるパルプのリグニンが，䅫濁液中の繊維粗度 に与える効果を示している。蒸解と漂白工程では, 纎 維からリグニンとへミセルロースを取り除いて, 纎維 粗度を減少させている。他に, 平均粗度と照濁液中の 繊維粗度分布を変える方法として, 繊維を分類して違 う絾維を混合する方法がある。

繊維粗度は，顕微鏡的方法と自動繊維分析器を用い て測定するとこが出来る。粗度の測定と粗度が紙質に 与える効果は, 数多く研究により提出されてきた。粗 度測定に於いて, 潜在的に起こりうる問題は粗度の概 念自体から引き起こされる。つまり, 纎維粗度は, 破 裂線を横断する部分の大きさによって求まるものであ る。即ち, 纎維の直径, 繊維の壁の厚さ（セルウォー ルシックネス), 壁の密度である。このようなことから， 巾の狭い，厚い壁を持った繊維粗度が，巾の広い，薄 い壁を持った繊維粗度と同じであるかもしれないと言 えるのである。しかもなお， 巾広の薄い壁を持つ纎維 


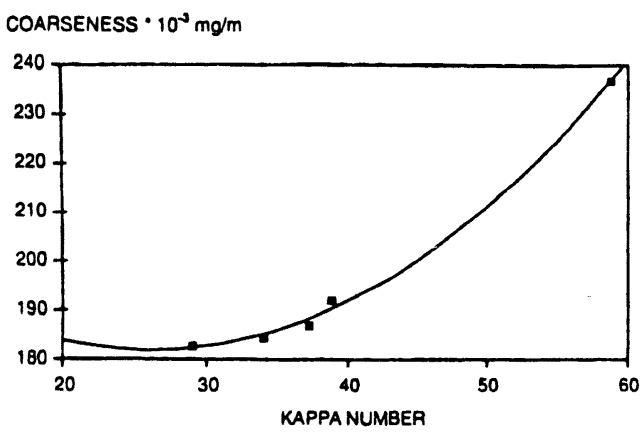

Fig.10 Effect of delignification degree on coarseness ; softwood kraft fibers/21/.

は，巾狭の厚い壁を持つ纎維より柔らかで，結合が容 易であるとも言える。例をあげると，あるレベルのセ ルウォールシックネスで比較した時，チップ化した後 (saw mill 後)の綫維は他の繊維よりも非常に高い粗 度が得られることが分かる。しかし, 壁の密度が肉厚 の壁と巾狭のセルに対して増加した時には（同じ破裂 線を横断する部分を持つ) パルプ繊維は，ほとんど同 一の粗度を与える (図 11 参照)。言い換えると, 纎維 粗度は繊維巾と繊維の壁の厚みを測定することによっ て求めることができる。さらに，粗度は繊維の壁の厚 みだけのパラメーターで表示することも可能である (図 12 参照)。

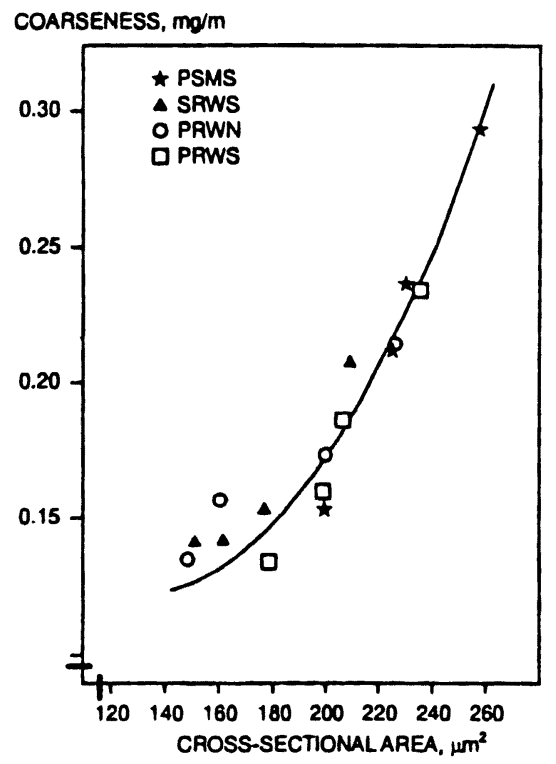

Fig.11 Relationship between cross-sectional area and coarseness ; softwood kraft fivres/1/.
繊維粗度は，未処理の繊維と均一にならされた繊維 (ルーメンの崩壊）との区別が出来ない。それにもか かわらず，均一化されたか崩壊した繊維は，その柔ら かさと結合能力と紙力において顕著な役割を演じてい る。粗度は，破裂線を横断する綫維の分布に対して対 応していないので, この情報を得るためには, 繊維巾 と壁の厚みを高い精度で測定する必要がある。一方で は，紙の光学的性質と紙力は，粗度を使って計算され ている。図 13 と図 14 に示寸研究結果によれば，粗度 範囲の $0.125 \sim 0.247 \mathrm{mg} / \mathrm{m}$ においては, 粗度は引っ 張り強さ及び引き裂き強さの全変数の $80 \%$ 以上を説 明できる。粗い瀻維は低い結合能力しか持たないので, 繊維粗度が増加した時に, 引っ張り強さが減少する。 しかも, 粗度はペーパーシート密度と空気の透過性の 変数の $70 \%$ 以上を説明出来了（図 15, 図 16 参照)。 この結果は, 統計的に大変重要なものである。粗い繊 維は, 広いネットワークを形作る。それゆえ, 高い精 度の範囲でそのシート密度は低くなり, 空気の透過性 は高くなる。

纎維長と粗度でもぺーパーシートの編成に影響する。 纎維の編成能力は, その質量に依存することがわかる。 質量は, 纎維長と粗度により求まる（方程式 1 と図 17 参照)。

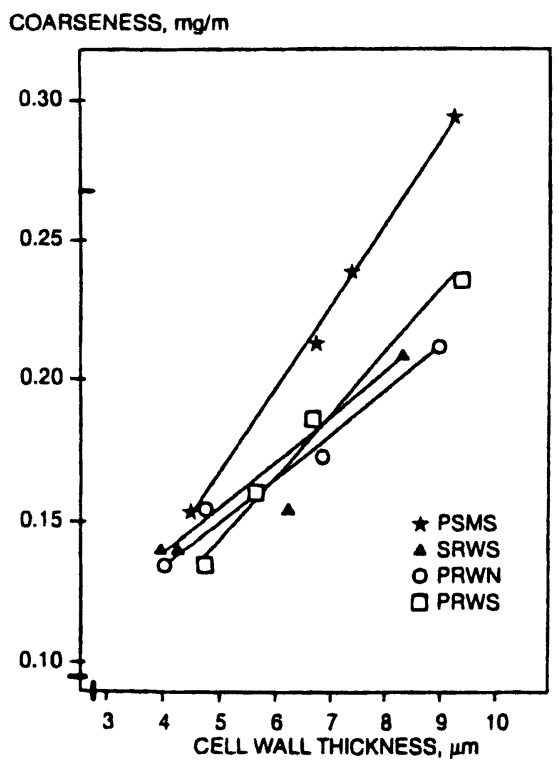

Fig.12 Relationship between cell wall thickness and fiber coarseness; softwood kraft fibres/1/. 


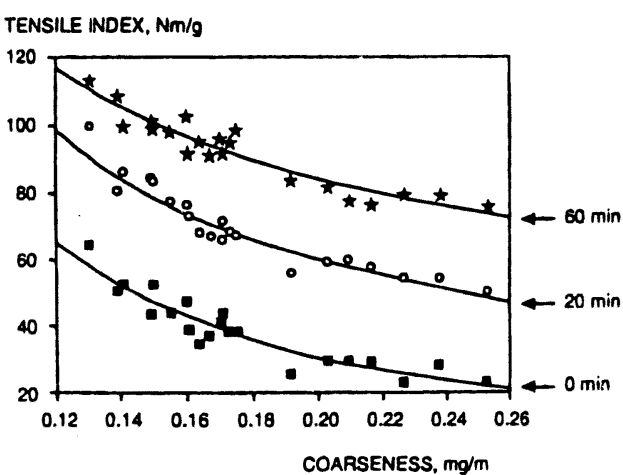

Fig.13 Effect of coarseness on the tensile strength of different softwood species; different beating degrees/1/.

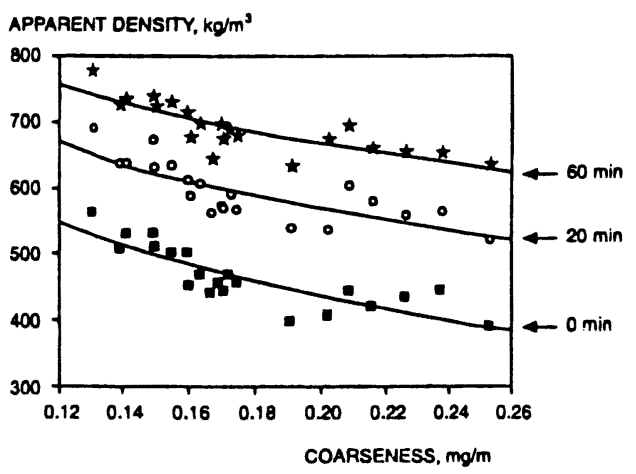

Fig.15 Effect of coarseness on the apparent sheet density of different softwood species; different beating degrees/1/.

Equation I:
\[ \begin{array}{l}N_{\text {pot }}=0.147+0.622 \sqrt{L \delta} \\ \text { where } \quad N_{\text {pot }}=\text { formation potential } \\ L=\text { length weighted fiber length } \\ \delta=\text { fiber coarseness }\end{array} \]

Fig.17 Formation potential as a function of the mass of a single fiber $/ 33 /$.

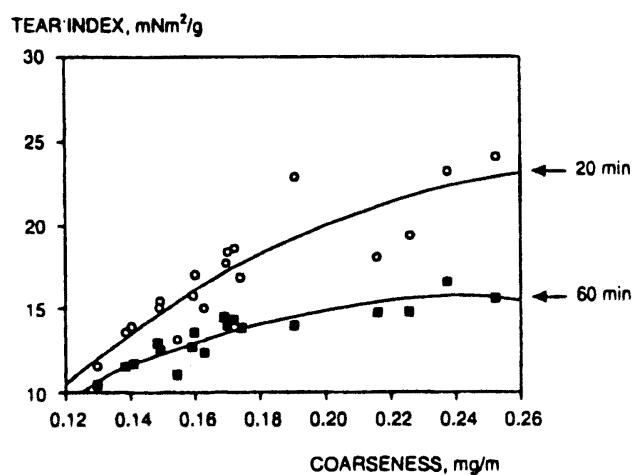

Fig.14 Effect of coarseness on the tear strength of different softwood species; different beating degrees/1/.

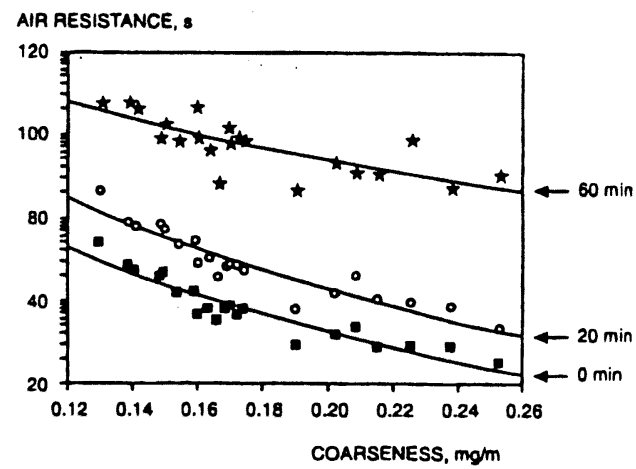

Fig.16 Effect of coarseness on the air resistance (Gurley) of different softwood species; different beating dregrees/1/.

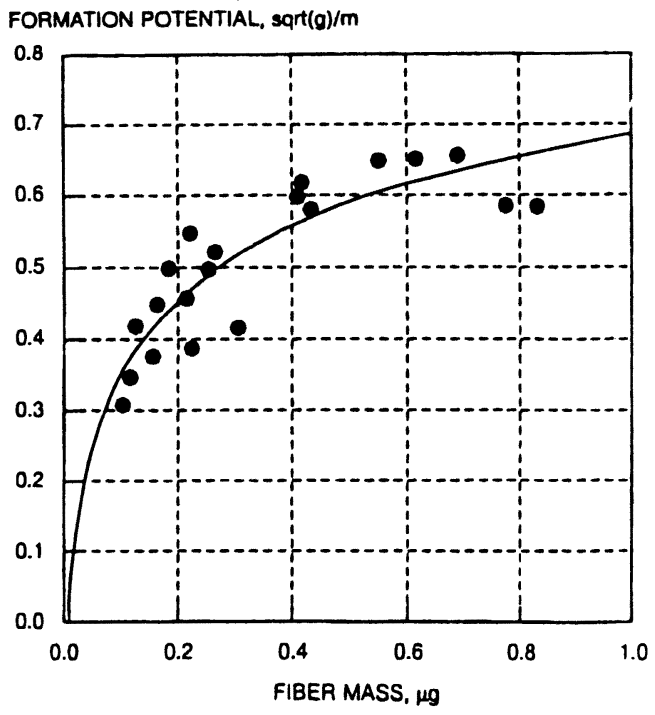


2.3 繊維の巾（太さ）とセルウォールシックネス (壁の厚み)

繊維の性質は，3つのカテゴリーに分けられる。形 態的分類（セルウォールシックネス，繊維巾，緘維 長)，構造的分類（繊維の曲がり，透明度，繊維壁の 薄い部分)，そして化学的分類（組成）である。もの の本によれば, 紙質に関して最も重要な繊維の性質は, セルウォールシックネスということである。ソフトウ ッドにより製紙生産力は, 主にパルプ原料の形態的性 質により決まるということで，製紙において決め手と なる形態的性質はセルウォールシックネスなのである。 パルプ原料が変化したとき，それに対応したセルウ オールシックネスの変化は, 纎維長 1.9 2.5 mmの 範囲, セルウォールシックネス $4 \sim 9 \mu \mathrm{m}$ の範囲中で, 補強パルプの決め手となる製紙材料の $80 \%$ 以上を説 明出来る。即ちそれは, $99 \%$ の信頼性をもって強度と 印刷力について説明出来るということである。

繊維の巾（太さ）は，七ルウォールシックネスのよ うな主因を持つデータで表すことは出来ない。しかし， 図 18 に示すよjに，七ルウォールシックネスと同時 に変化することを忘れてはならない。これは，春の木 材 (巾広, 薄壁の繊維) と夏の木材 (巾狭, 厚壁の繊 維）との間の違いからもたらされる結果なのである。 纎維の柔軟性と崩壊に対する抵抗力は, 主に, 七ルウ オールシックネスで決まる。繊維の柔軟性と崩壊は, 繊維と繊維の結合によっており，その主な理由は繊維 表面の結合力增大により引っ張り強さが増すからであ る。厚壁を持った堅い繊維は粗い表面を持ち（図 19）,

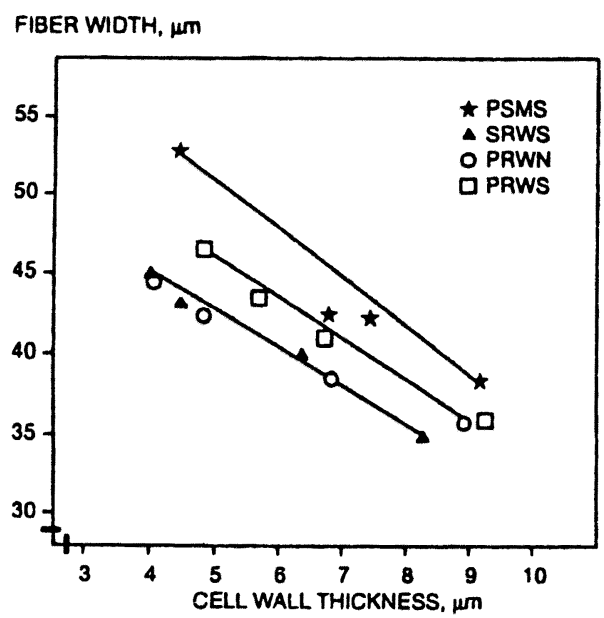

Fig.18 Relationship between cell wall thickness and fiber width with different soft-. woods $/ 1 /$.
高い空気透過性と弱い紙力を持った，広く緩やかなネ ットワークを形成する (図 20 と図 21 参照)。

未叮解繊維については，引き裂き強さの低下がセル ウォールシックネスの増加と線形関係にあり，また， 吒解繊維には，それと逆の関係がある(図 22 参照)。

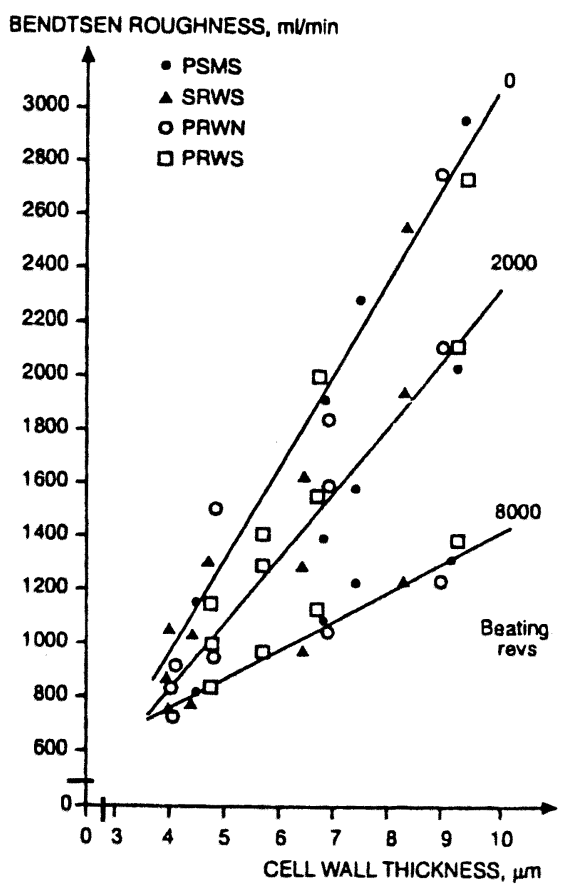

Fig.19 Effect of cell wall thickness on paper roughness; softwood kraft fibers/24/.

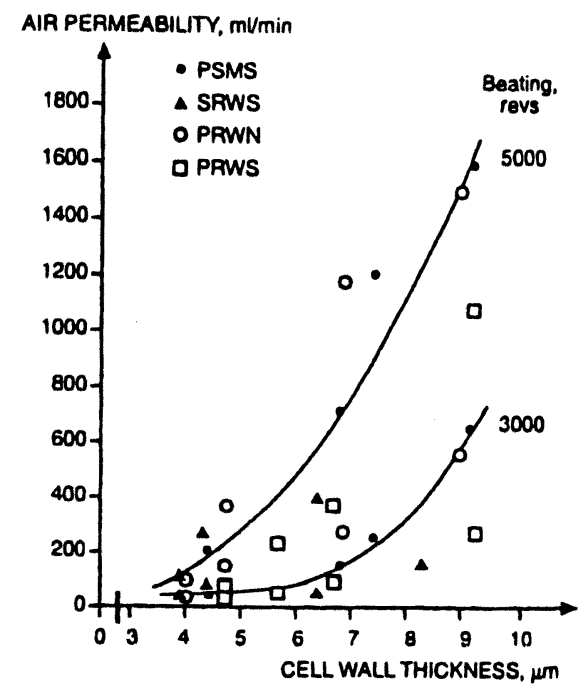

Fig.20 Effect of cell wall thickness on air permeability; softwood kraft fibers/24/. 


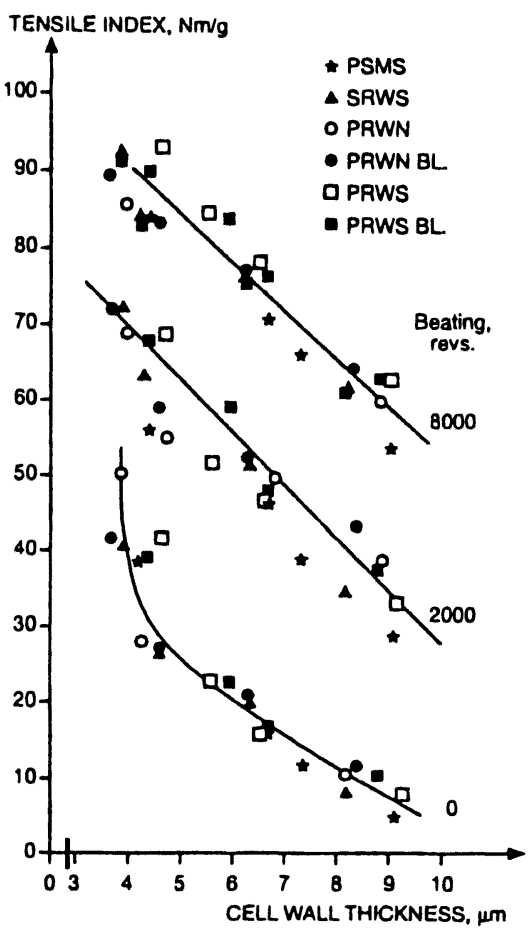

Fig.21 Effect of cell wall thickness on tensile strength; softwood kraft fibers/26/.
薄壁を持つ纎維は強い引き裂き強さを与えるが, 最 大強さを追求すれば, 繊維はある結合力を持つ必要が ある。このことは, 未叮解の堅く厚壁を持つ纎維が, 薄壁を持つ繊維よりも弱い引き裂き強さを持つことの 理由を説明している。

散乱光の効果は, 繊維ネットワーク（纎維数, 破壊 部分を横断する緎維の大きさ，ルーメンの破壊力）の 結合力と全表面積により決まる。厚いセルウォールシ ックネスにより散乱光の効果は減少し, 図 23 の様に 未吒解繊維に対してはっきりする。つまり，未吒解繊 維の散乱光能力が, 緎維ネットワークの全表面積の大 きさに従って強くなることが明らかである。

また, セルウォールシックネスは吒解の程度により 比例する (図 24 参照)。この意味するところは, リフ アイニングプロセス制御に対して有効であることを表 わしている。更に, 蒸解及び漂白中に繊維壁の中へ浸 透する薬品の効果も表わす。

このように絾維には様々な特徴があり, 紙の品質に 大きな影響を与える。䌘社の繊維長測定器は, 繊維の 特性を生かした測定器である。次に新しく開発された カヤーニ FiberLab 繊維分析器について, 述べていく。
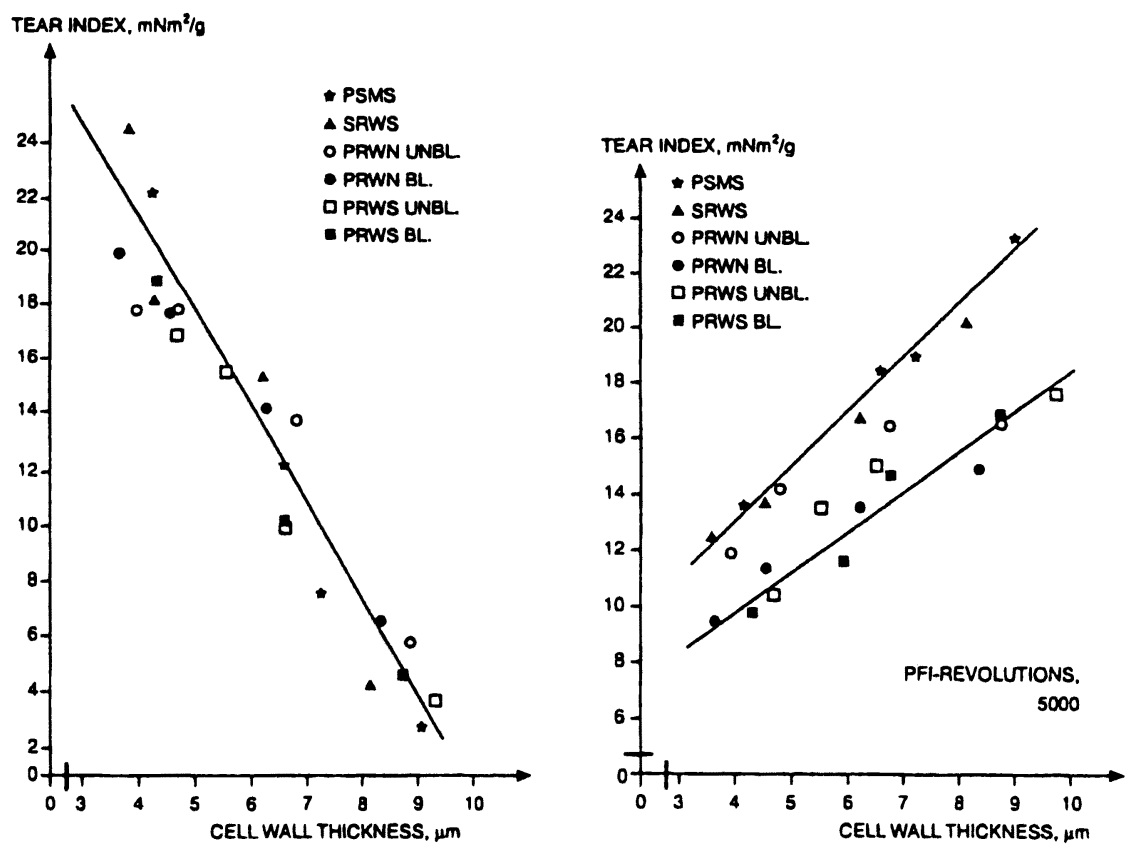

Fig.22 Effect of cell wall thickness on tear strength; softwood kraft fibers/ $26 /$. 
LIGHT SCATTERING COEFFICIENT, $\mathrm{m}^{2} / \mathrm{kg}$

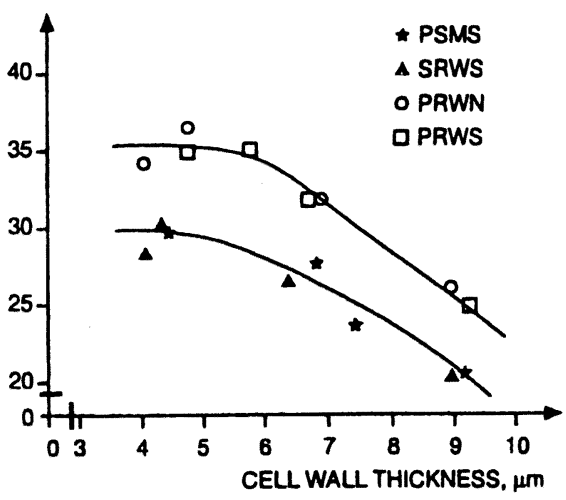

LIGHT SCATTERING COEFFICIENT, $\mathrm{m}^{2} \mathrm{~kg}$

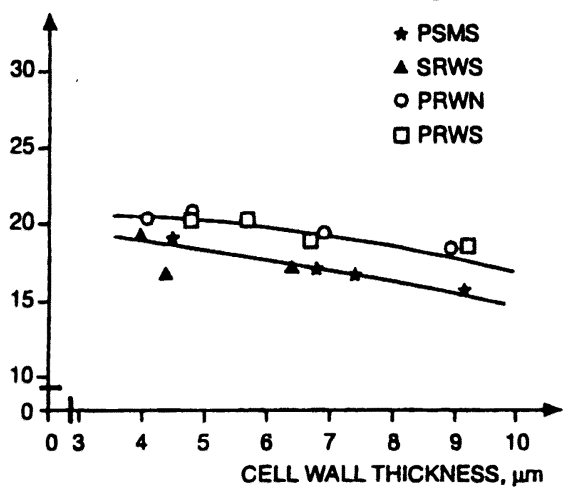

Fig.23 Effect of cell wall thickness on the light scattering coefficient; softwood kraft fibers/26/.

BEATING, revs.

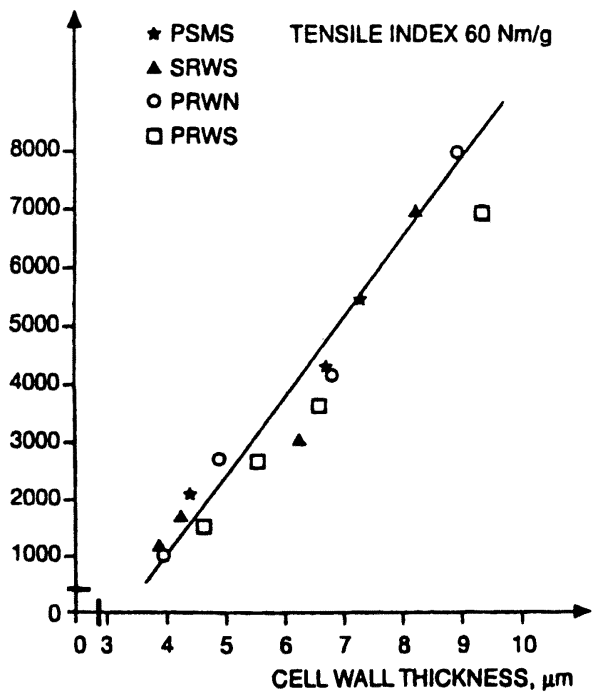

Fig.24 Effect of cell wall thickness on beating degree; softwood kraft fibers/24/.

\section{3. カヤーニ FiberLab 繊維分析器の特徵}

パルプ原料から吒解 (Beater) やリファイン等の 精選工程を経て変化する繊維の物性を把握することは, 紙の品質管理工程において重要な指標であり，䋐維粗 度 (コースネス) から引き裂き強度（Tear）へつな がる目的の紙品質を安定化させることになる。

15 年以上前（1982 年）に，第一世代型繊維長分析 器カヤーニ FS-100 が新しい繊維测定法として紹介さ れた。そして，10 年前（1987 年）に引き続いて研究 開発された全自動繊維分析器カヤーニ FS-200 が立ち 上がった。(Launch) さらに，5年前（1993 年）にオ ンライン型繊維長分析器カヤーニ FSA が製紙工場に 導入された。バルメットオートメーションカヤーニは, 自動繊維分析装置のために 15 年以上にわたり研究開 発にかかわりイノベーションを推進してきた。

すでに，700のカヤー二繊維長分析器が導入され世 界の国々で愛用されている。

そしてこのたび，繊維測定の最新技術により実現し 提供されたのが, FiberLabである。今まで以上の情 報を知ることにより，最上の紙品質を安定的に供給で きる。況長で時間のかかる電子顕微鏡に代わる研究用 機器である。

\section{1 緎維長 $(\mathbf{F})$, 織維幅 $(\mathbf{F}, \mathbf{W})$, そして} セルウォールシックネス $(\mathrm{C}, \mathrm{W}, \mathrm{T})$

カヤーニ FiberLab は, TAPPI T 271 試験法に従 った全自動繊維長測定器で, 加えて繊維幅と C.W.T (繊維の壁の厚み) を測定できる。進化した画像分析 技術と，業界における世界のリーダーカンパニーとし て 15 年以上にわたり培ってきた技術を駆使して， FiberLab は最新型自動分析器の代名詞となるであろ う。この装置の新しいオプティカル技術により，1 1 ミ クロンの分解能で F.W と C.W.T が， 5 ミクロンの 感度と 50 ミクロンの分解能で $\mathrm{F}$ (繊維長) が測定で きるようになった。

\section{2 機 器 概 要}

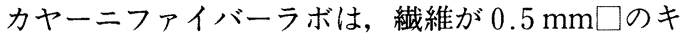
ヤピラリーを通過する間に, 繊維長と, 繊維幅, 七ル ウォールシックネス（細胞膜壁厚）を同時に測定する。 繊維長は,レーザー光線による繊維の持つ偏光に対す る特性を利用して, パルプ液が, 図 25 中のキャピラ リー状のセル $(0.5 \mathrm{~mm} \square)$ を通過する間に計測する。

セルの中を通るパルプ液の透過光の内で, パルプ繊 維により複屈折した光の作る投映像をディテクター （図 25 の 6) で検知して，繊維の長さを測定している。 同時に繊維長とは，90方向ずれた方向から，キセノ 


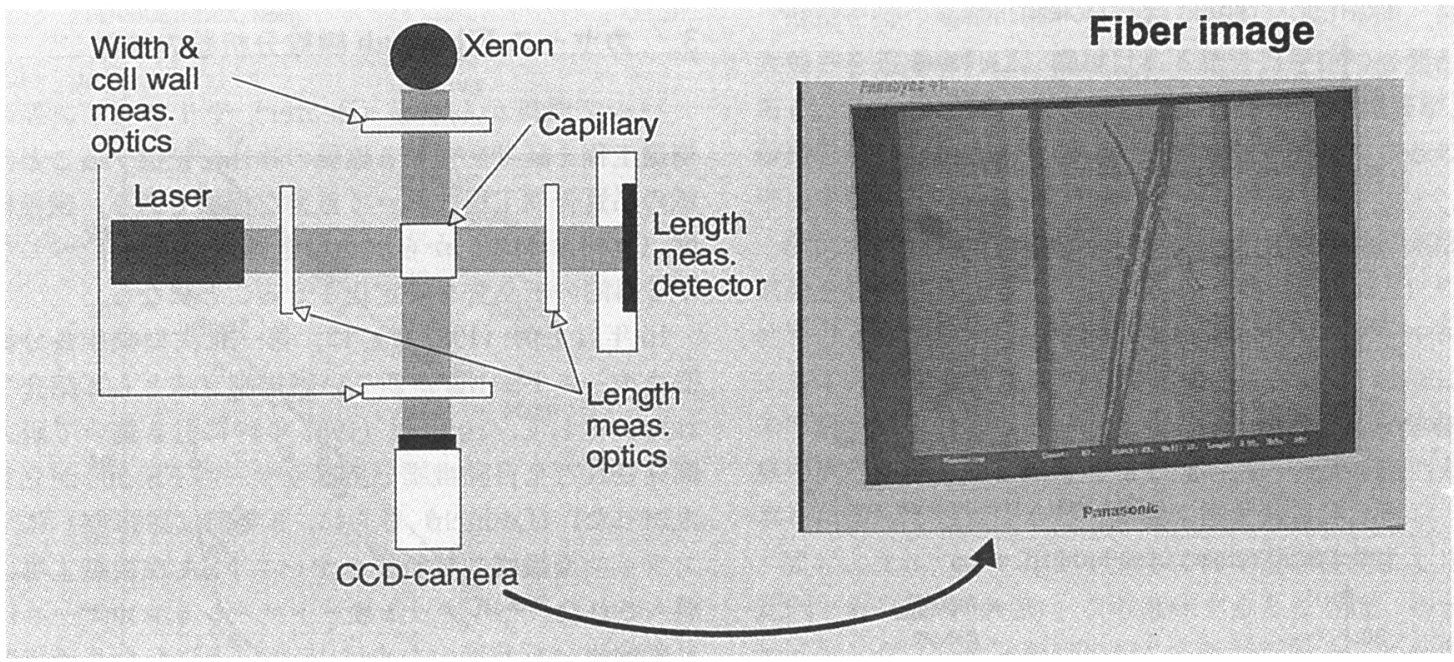

Fig. 25 測定原理

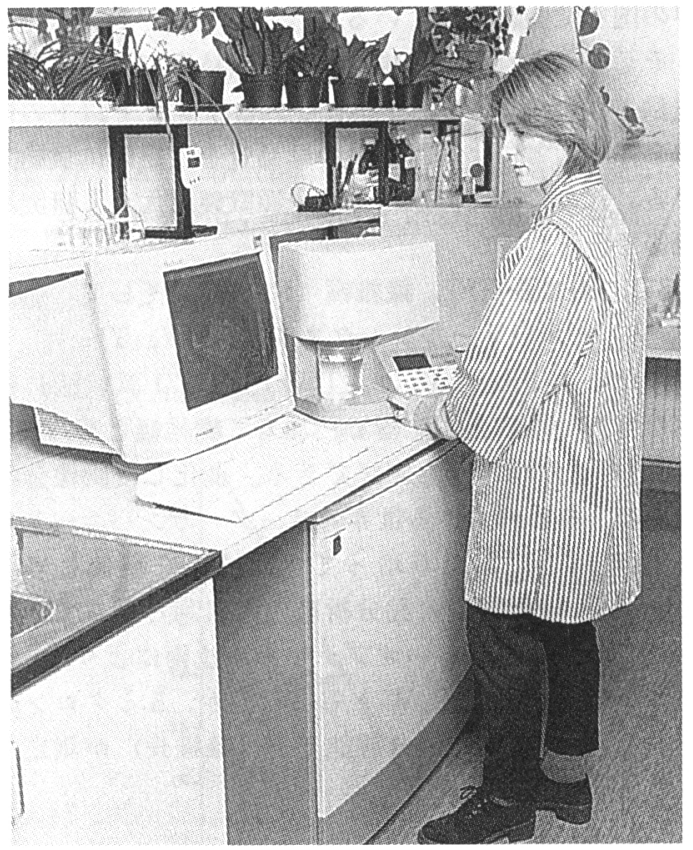

（写真） Kajaani FiberLabの外観

ン光をあて CCD カメラを利用して,画像解析によっ て, 繊維幅及び細胞膜壁厚を測定している。

サンプルを测定位置に置けば，希釈，測定，洗浄及 びレポートを全自動で行い, 繊維長, 繊維幅, 細胞膜 壁厚, 繊維粗度, 異種材の混合比率等を算出します。 また，測定中の詰まりの自動除去や，自己診断機能を
備えている。

\section{3 機器構成}

$$
\text { カヤーニファイバーサイズアナライザーは, アナラ }
$$
イザーユニット, サンプルユニットと付属消耗品とで 構成される。

(1) アナライザーユニット：ペンティアムとセンサ 一による画像解析装置, 測定及びコントロール用 エレクトロニクス, 光学測定部, CCD カメラ, 圧力エアを使った真空装置, 測定済みサンプル用 容器及び容器からの自動排出装置。

(2) サンプリングユニット：測定器操作のためのキ 一ボードと試料の自動取扱機構が組み込まれてい る。

3.4 仕様

測定項目と仕様は以下のとおりである。

(1) 繊維長測定

- 測定範囲 : 0 7.6 mm

・分 解能: $50 \mu \mathrm{m}$

・測定速度：最高毎秒 90 fibers

- 分析時間：約 8 分

\section{（2）纎維幅及び細胞膜壁厚}

・測定範囲：0 200 $\mu \mathrm{m}$ (幅)

- 分解能: $1 \mu \mathrm{m}$

・測定速度：5 10 本/秒

-分析時間：約 8 分（繊維長と同時測定）

(3) 繊維粗度演算

（4） L 材/ $\mathrm{N}$ 材 混合比率計算 